\title{
Mesorhizobium chacoense sp. nov., a novel species that nodulates Prosopis alba in the Chaco Arido region (Argentina)
}

\author{
1 Departamento de \\ Microbiología y Genética, \\ Edificio Departamental, \\ Campus Miguel de \\ Unamuno, Universidad de \\ Salamanca, Salamanca, \\ Spain \\ 2 IRNA-CSIC, Apartado 257, \\ Salamanca, Spain \\ 3 Catedra de Microbiología \\ Agrícola, Facultad de \\ Agronomía, Universidad \\ de Córdoba, Córdoba, \\ Argentina \\ 4 Laboratoire d'Ecologie \\ Microbienne, Unite de \\ Recherche Associeé au \\ CNRS 697, Université Lyon \\ 1, F-69622 Villeurbanne \\ cedex, France \\ 5 Laboratorium voor \\ Microbiologie, Vakgroep \\ Biochemie, Fysiologie en \\ Microbiologie, K. L. \\ Ledeganckstraat 35, \\ B-9000 Gent, Belgium \\ 6 Departamento de Sistemas \\ Simbióticos, Estación \\ Experimental del Zaidín, \\ CSIC, Granada, Spain
}

\author{
Encarna Velázquez, ${ }^{1}$ José Mariano Igual, ${ }^{2}$ Anne Willems, ${ }^{5}$ \\ María P. Fernández, ${ }^{4}$ Estefanía Muñoz, ${ }^{6}$ Pedro F. Mateos, ${ }^{1}$ \\ Adriana Abril, ${ }^{3}$ Nicolás Toro, ${ }^{6}$ Phillippe Normand, ${ }^{4}$ \\ Emilio Cervantes, ${ }^{2}$ Monique Gillis ${ }^{5}$ and Eustoquio Martínez-Molina ${ }^{1}$
}

Author for correspondence: Encarna Velázquez. Tel: +34923 294532. Fax: + 34923224876. e-mail: evp@gugu.usal.es

\begin{abstract}
Low-molecular-weight RNA analysis was performed for the identification and classification of $\mathbf{2 0}$ Argentinian strains isolated from the root nodules of Prosopis alba. SDS-PAGE of total cellular proteins, determination of the DNA base composition, DNA-DNA reassociation experiments and physiological and biochemical tests were also carried out for these strains and the whole $16 \mathrm{~S}$ rRNA gene was sequenced from one of the strains, strain LMG 19008'. Results of the genotypic and phenotypic characterization showed that the strains isolated in this study belong to a group that clustered in the genus Mesorhizobium. The results of DNA-DNA hybridizations showed that this group is a novel species of this genus. The name Mesorhizobium chacoense sp. nov. is proposed for this species. The type strain is LMG $19008^{\top}$ (= CECT $5336^{\top}$ ).
\end{abstract}

Keywords: taxonomy, Mesorhizobium, LMW RNA, 16S rRNA, Prosopis

\section{INTRODUCTION}

The taxonomy of the family Rhizobiaceae has been the subject of important advances in recent years. Six genera are able to nodulate diverse species of legumes: Rhizobium, Bradyrhizobium, Azorhizobium, Sinorhizobium, Mesorhizobium and Allorhizobium. In the early years of Rhizobium taxonomy, species were, in general, described from legumes of agronomic importance, but a trend in recent years to investigate the symbionts of exotic plants has resulted in important contributions to rhizobial taxonomy. Thus, Azorhizobium was defined as a new genus based on strains able to nodulate the stems of Sesbania rostrata (Dreyfus et al., 1988) and Allorhizobium was isolated from an aquatic legume, Neptunia natans, in Senegal (de Lajudie et al., 1998b). Also, the analysis of rhizobial symbionts of leguminous trees of the genus

Abbreviations: LMW RNA, low-molecular-weight RNA; PNP, para-nitrophenyl substrates; SCE, staircase electrophoresis.

The GenBank accession number for the 16S rRNA sequence of Mesorhizobium chacoense LMG $19008^{\top}$ is AJ278249.
Acacia from Senegal resulted in the description of various species of Sinorhizobium (de Lajudie et al., 1994) and Mesorhizobium (de Lajudie et al., 1998a; Wang et al., 1999). The species Mesorhizobium plurifarium contained strains isolated from nodules of Acacia, Leucaena, Prosopis and Chamaecrista in West Africa (Senegal), as well as East Africa (Sudan) and South America (Brazil). Nevertheless, a large number of legumes exists whose bacterial symbionts have not been studied systematically. Thus, in general, isolation of their bacterial symbionts is a promising strategy to increase our knowledge of the systematics and evolution of Rhizobium. Moreover, many of these rhizobia that remain as yet unexamined have established symbiotic relationships with legumes that are of great importance in the maintenance and economy of large and important ecosystems throughout the world. Therefore, knowledge and optimization in the management of these ecosystems may benefit from the study of these particular strains. Species of the genus Prosopis are important trees in many ecosystems throughout South America and some have been introduced into Africa, where they can be nodulated by indigenous rhizobia (de Lajudie et al., 1998a; 
Haukka et al., 1996; McInroy et al., 1999). Apart from the above references, little work has been described concerning the taxonomy of American rhizobial symbionts of Prosopis. In this work, rhizobial strains have been isolated from Prosopis chilensis plants growing in diverse geographical locations in central Argentina, including the Reserva Chancaní in the south of El Chaco Arido, an important ecosystem, covering several thousands of hectares in Argentina. Based on a polyphasic taxonomy approach, including staircase electrophoresis analysis (SCE) of low-molecularweight (LMW) RNA, 16S rDNA sequencing, analysis of total cell protein, determination of base composition and DNA-DNA hybridization and a series of biochemical tests, the novel species Mesorhizobium chacoense is described.

\section{METHODS}

Bacterial strains. The reference strains and novel isolates used in this study are listed in Table 1. A total of 20 new rhizobial isolates was obtained from young Prosopis alba plants growing in soil from two different locations. Nine isolates were from Luque, located some $200 \mathrm{~km}$ east of Cordoba Province in the Espinal region, and eleven isolates were from the Chancaní reserve, in the north-west of Cordoba Province in the Chaco Arido region (Argentina). Isolations were made according to Vincent (1970) using yeast mannitol agar [YMA, which contained $\left(\mathrm{g}^{-1}\right)$ : mannitol, 10; sodium glutamate, $0.5 ; \mathrm{K}_{2} \mathrm{HPO}_{4}, 0.5$; $\mathrm{MgSO}_{4} .7 \mathrm{H}_{2} \mathrm{O}, 0 \cdot 2 ; \mathrm{NaCl}, 0.05 ; \mathrm{CaCl}_{2}, 0.04 ; \mathrm{FeCl}_{3}, 0.004$; yeast extract, 1; agar, 20; pH 6.8] (Bergersen, 1961). The cultures used in further studies were purified from single colonies after $10 \mathrm{~d}$ incubation at $28^{\circ} \mathrm{C}$.

Nodulation tests. Surface-sterilized seeds of $P$. chilensis, $P$. alba, Prosopis flexuosa and Acacia sp. were heat treated $\left(50{ }^{\circ} \mathrm{C}\right.$ for $5 \mathrm{~min}$ ) and germinated axenically in Petri dishes. Seedlings were transferred to pots with sterile vermiculite and watered with nitrogen-free nutrient solution (Rigaud \& Puppo, 1975). Each plant was inoculated with $10 \mathrm{ml}$ of a suspension of each strain containing $8 \times 10^{8}$ cells $\mathrm{ml}^{-1}$. The inoculated plants were placed for $30 \mathrm{~d}$ in a plant growth chamber with mixed incandescent and fluorescent lighting (400 microeinsteins $\mathrm{m}^{-2} \mathrm{~s}^{-1} ; 400-700 \mathrm{~nm}$ ), programmed for a $16 \mathrm{~h}$ photoperiod day/night cycle, at a constant tem-

Table 1. Strains used in this study

Abbreviations: ATCC, American Type Culture Collection, Manassas, VA, USA; LMG, Collection of Bacteria of the Laboratory voor Microbiologie, Gent, Belgium; CECT, Spanish Type Culture Collection, Valencia, Spain.

\begin{tabular}{|c|c|c|c|c|}
\hline Strain & LMG no.* & Host plant & Geographical origin $\dagger$ & Reference \\
\hline \multicolumn{5}{|l|}{ Mesorhizobium chacoense } \\
\hline $\operatorname{Pr}-5^{\mathrm{T}}\left(=\mathrm{CECT} 5336^{\mathrm{T}}\right)$ & LMG $19008^{\mathrm{T} 1,2}$ & Prosopis alba & Chancaní & This study \\
\hline $\operatorname{Pr}-11$ & LMG $19009^{1}$ & Prosopis alba & Chancaní & This study \\
\hline Pch-1 & LMG $19010^{1}$ & Prosopis alba & Chancaní & This study \\
\hline Pch-2 & LMG $19011^{1}$ & Prosopis alba & Chancaní & This study \\
\hline Pch-3 & LMG $19012^{1}$ & Prosopis alba & Chancaní & This study \\
\hline Pch-4 & LMG $19013^{1}$ & Prosopis alba & Chancaní & This study \\
\hline Pch-5 & LMG $19014^{1}$ & Prosopis alba & Chancaní & This study \\
\hline Pch-6 & LMG $19015^{1}$ & Prosopis alba & Chancaní & This study \\
\hline Pch-7 & LMG $19016^{1}$ & Prosopis alba & Chancaní & This study \\
\hline Pch-8 & LMG $19017^{1}$ & Prosopis alba & Chancaní & This study \\
\hline Pch-9 & LMG $19018^{1}$ & Prosopis alba & Chancaní & This study \\
\hline Pl-1 & LMG $19019^{1}$ & Prosopis alba & Luque & This study \\
\hline $\mathrm{Pl}-3$ & LMG $19020^{1}$ & Prosopis alba & Luque & This study \\
\hline Pl-5 & LMG $19021^{1}$ & Prosopis alba & Luque & This study \\
\hline Pl-6 & LMG $19022^{1,2}$ & Prosopis alba & Luque & This study \\
\hline Pl-7 & LMG $19023^{1}$ & Prosopis alba & Luque & This study \\
\hline $\mathrm{Pl}-8$ & LMG $19024^{1}$ & Prosopis alba & Luque & This study \\
\hline $\mathrm{Pl}-10$ & LMG $19025^{1}$ & Prosopis alba & Luque & This study \\
\hline Pl-11 & LMG $19026^{1}$ & Prosopis alba & Luque & This study \\
\hline $\mathrm{Pl}-12$ & LMG $19027^{1}$ & Prosopis alba & Luque & This study \\
\hline Mesorhizobium loti ATCC $33669^{\mathrm{T}}$ & LMG $6125^{\mathrm{T} 1,2}$ & Lotus tenuis & New Zealand & Jarvis et al. (1982) \\
\hline Mesorhizobium loti NZP 2014 & LMG $6124^{2}$ & Lotus corniculatus & New Zealand & Jarvis et al. (1982) \\
\hline Mesorhizobium ciceri USDA $3383^{\mathrm{T}}$ & LMG $14989^{\mathrm{T} 1,2}$ & Cicer arietinum & Spain & Nour et al. (1994) \\
\hline Mesorhizobium mediterraneum UPM-CA142 & LMG $14990^{2}$ & Cicer arietinum & Spain & Nour et al. (1995) \\
\hline Mesorhizobium mediterraneum USDA $3392^{\mathrm{T}}$ & - & Cicer arietinum & Spain & Nour et al. (1995) \\
\hline Mesorhizobium tianshanense USDA $3592^{\mathrm{T}}$ & LMG $15767^{\mathrm{T} 1,2}$ & Glyzyrrhiza pallidiflora & China & Chen et al. (1995) \\
\hline Mesorhizobium huakuii USDA $4779^{\mathrm{T}}$ & LMG $14107^{\mathrm{T} 1,2}$ & Astragalus sinicus & China & Chen et al. (1991) \\
\hline Mesorhizobium plurifarium LMG $11892^{\mathrm{T}}$ & LMG $11892^{\mathrm{T} 2}$ & Acacia senegal & Senegal & de Lajudie et al. (1998a) \\
\hline Mesorhizobium amorphae ACCC $19665^{\mathrm{T}}$ & LMG $18977^{\mathrm{T} 1,2}$ & Amorpha fruticosa & China & Wang et al. (1999) \\
\hline Sinorhizobium meliloti USDA $1002^{\mathrm{T}}$ & LMG $6133^{\mathrm{T}}$ & Medicago sativa & USA & de Lajudie et al. (1994) \\
\hline Rhizobium leguminosarum ATCC $10004^{\mathrm{T}}$ & LMG $8817^{\mathrm{T}}$ & Pisum sativum & USA & Skerman et al. (1980) \\
\hline Rhizobium galegae ATCC $43677^{\mathrm{T}}$ & LMG $6214^{\mathrm{T}}$ & Galega orientalis & Finland & Lindström (1989) \\
\hline Azorhizobium caulinodans ATCC $43989^{\mathrm{T}}$ & LMG $6465^{\mathrm{T}}$ & Sesbania rostrata & Senegal & Dreyfus et al. (1988) \\
\hline Bradyrhizobium japonicum ATCC $10324^{\mathrm{T}}$ & LMG $6138^{\mathrm{T}}$ & Glycine $\max$ & Japan & Jordan (1982) \\
\hline Allorhizobium undicola & LMG $11875^{\mathrm{T}}$ & Neptunia natans & Senegal & de Lajudie et al. (1998b) \\
\hline Agrobacterium tumefaciens ATCC $23308^{\mathrm{T}}$ & LMG $187^{\mathrm{T}}$ & & & Kersters \& De Ley (1984) \\
\hline Phyllobacterium myrsinacearum ATCC $43590^{\mathrm{T}}$ & LMG $6465^{\mathrm{T}}$ & Ardisia crispa & & Knösel (1984) \\
\hline
\end{tabular}

* Strains marked with ' 1 ' were included in LMW RNA analysis. Strains marked with '2' were used in DNA-DNA hybridization. $\dagger$ Chancaní and Luque are two regions of Argentina. 
perature of $25-27{ }^{\circ} \mathrm{C}$ and $50-60 \%$ relative humidity. Root nodules appeared 2 months after inoculation.

RNA extraction and LMW RNA profile analysis. The LMW RNA of the strains studied was extracted as described by Höfle (1988). LMW RNA profiles were obtained using SCE in $14 \%$ polyacrylamide gels under denaturing conditions in steps of $10 \mathrm{~min}$, rising through a constant ramp with $50 \mathrm{~V}$ increases from 100 to $2300 \mathrm{~V}$, as reported previously (CruzSánchez et al., 1997). The following commercial molecules, from Boehringer Mannheim and Sigma, were used as references: 5S rRNA from Escherichia coli MRE 600 (120 and $115 \mathrm{nt}$ ) (Bidle \& Fletcher, 1995), tRNA specific for tyrosine from E. coli $(85 \mathrm{nt})$ and tRNA specific for valine from E. coli (77 nt) (Sprinzl et al., 1985). Samples were prepared as reported elsewhere (Cruz-Sánchez et al., 1997). After electrophoresis, the gels were silver-stained as described by Haas et al. (1994).

Determination of nucleotide sequences of the 16S rRNA genes and analysis of the sequence data. Amplification of the whole $16 \mathrm{~S}$ rDNA was performed using the PCR primers FGPS 1509.153 (5'-AAGGAGGGGATCCAGCCGCA-3') and FGPS 4.281 [5'-ATGGA(GA)AG(TC)TTGATCCTGGCTCA-3'] (Normand et al., 1996) in a GeneAmp PCR system 2400 thermocycler (Perkin-Elmer) under the following conditions: initial denaturation for $3 \mathrm{~min}$ at $94{ }^{\circ} \mathrm{C}$; 35 cycles of denaturation $\left(1 \mathrm{~min}\right.$ at $\left.94^{\circ} \mathrm{C}\right)$, annealing $(45 \mathrm{~s}$ at $60{ }^{\circ} \mathrm{C}$ ) and extension $\left(1 \mathrm{~min}\right.$ at $\left.72{ }^{\circ} \mathrm{C}\right)$; final extension for $7 \mathrm{~min}$ at $72{ }^{\circ} \mathrm{C}$. The reaction volume was $50 \mu \mathrm{l}$ and contained $5 \mu \mathrm{l}$ cell suspension in $25 \%$ glycerol, $5 \mu \mathrm{l}$ buffer $(10 \mu \mathrm{M}$ Tris/ $\mathrm{HCl}, \mathrm{pH} 8.2 ; 1.5 \mathrm{mM} \mathrm{MgCl}_{2} ; 50 \mathrm{mM} \mathrm{KCl} ; 0.01 \%$, $\mathrm{w} / \mathrm{v}$, gelatin), $20 \mu \mathrm{M}$ each dNTP (Pharmacia Biotech), $0.5 \mu \mathrm{M}$ each primer and 2.5 U Taq DNA polymerase (GibcoBRL). PCR amplification of DNA was checked by agarose gel electrophoresis $(2 \%, \mathrm{w} / \mathrm{v})$ in Tris/borate/EDTA buffer. The PCR amplification products were visualized by ethidium bromide staining. Before sequencing, the amplification mixture was purified with a QIAquick kit (Qiagen).

Sequencing of the 16S rRNA gene (positions 58-1541 of the E. coli $16 \mathrm{~S}$ rDNA sequence) was performed by Genome Express, Grenoble, France. Sequences of both strands were determined using the following five oligonucleotides: $5^{\prime}$ TGGCTCAGAACGAACGCTGGCGGC-3', 5'-AGCCTTGCGGCCGTACTCCC3', 5'-CAGCAGCCGCGGTAA3', 5'-AAGGAGGGGATCCAGCCGCA-3' and 5'-GCCTGGGGAGCTCGGCCGCA-3', which correspond to positions 20-43, 518-532, 885-904, 1521-1540 and 880-899, respectively, of the $E$. coli small-subunit rDNA sequence (Normand et al., 1996; Ritchie \& Myrold, 1999).

The 16S rDNA of strains LMG $19008^{\mathrm{T}}$ and LMG 19009 was amplified. For LMG 19009, only a 900 bp fragment was obtained. This fragment showed $100 \%$ identity to the corresponding LMG $19008^{\mathrm{T}}$ zone and PCR-RFLP analysis of their $16 \mathrm{~S}$ rDNA using $C f_{o} \mathrm{I}$ and $\operatorname{In} f \mathrm{I}$ endonucleases gave identical patterns (data not shown). Consequently, only LMG $19008^{\mathrm{T}}$ was used for further analysis. The sequence was compared with previously published sequences of members of the Rhizobiaceae and other closely related species (see Fig. 2) as determined by BLAST software (Altschul et al., 1990). Sequences were aligned using the CLUSTAL $\mathrm{x}$ software (Thompson et al., 1997). Alignment was refined manually using the SUNMASE algorithm (Faulkner \& Jurka, 1988). The distances were calculated according to Kimura's two-parameter method (Kimura, 1980) and a dendrogram was obtained by the neighbour-joining algorithm (Saitou \& Nei, 1987).
Microplate DNA-DNA hybridization. Reference strains used in DNA-DNA hybridizations are listed in Table 1. Strains were grown on YMA or tryptone/yeast extract (TY) agar [containing $\left(\mathrm{g} \mathrm{l}^{-1}\right)$ : tryptone (Oxoid), 5; yeast extract (Oxoid), 0.75; $\mathrm{KH}_{2} \mathrm{PO}_{4}, 0.454 ; \mathrm{Na}_{2} \mathrm{HPO}_{4} .12 \mathrm{H}_{2} \mathrm{O}, 2.388$; $\mathrm{CaCl}_{2}, 1$; agar, 20 ; $\mathrm{pH} 6 \cdot 8-7 \cdot 0$ ] at $28^{\circ} \mathrm{C}$ for $2 \mathrm{~d}$. Total DNA was prepared by using the method of Pitcher et al. (1989), in which volumes were scaled up 30-fold to allow the use of a larger quantity of cells for extraction. Hybridizations were performed using the microplate method as described by Ezaki et al. (1989).

DNA base composition. DNA of two representative strains, LMG $19008^{\mathrm{T}}$ and LMG 19022, was degraded enzymically into nucleosides as described by Mesbah et al. (1989). The resulting nucleoside mixtures were separated by HPLC using a Waters Symmetry Shield C8 column at $37^{\circ} \mathrm{C}$. The solvent was $0.02 \mathrm{M} \mathrm{NH}_{4} \mathrm{H}_{2} \mathrm{PO}_{4}(\mathrm{pH} 4.0)$ with $1.5 \%$ acetonitrile. Non-methylated lambda phage DNA (Sigma) was used as the calibration reference.

Analysis of proteins by SDS-PAGE. Strains isolated from Prosopis in this study were grown at $28^{\circ} \mathrm{C}$ for $48 \mathrm{~h}$ on TY agar. Strains LMG 15767 and LMG 14990, which did not grow sufficiently on TY, were grown on YMA. Cellular protein extracts were prepared and SDS-PAGE was performed as described previously (Pot et al., 1994). Digitization, normalization and numerical analyses of the protein patterns were performed with the GELCOMPAR 4.0 software (Applied Maths) as described by Pot et al. (1994). The similarity between pairs of protein patterns is expressed by Pearson's product-moment correlation coefficient converted to percentages.

Plasmid profile analysis. The strains isolated were subjected to plasmid profile analysis according to Plazinski et al. (1985). Electrophoresis was modified as follows: electrophoresis was carried out at $30 \mathrm{~V}$ for $90 \mathrm{~min}$, at $60 \mathrm{~V}$ for $60 \mathrm{~min}$ and at $40 \mathrm{~V}$ for $3 \mathrm{~h}$. The plasmids of Sinorhizobium meliloti GR4, which has a cryptic plasmid of $140 \mathrm{MDa}$ and another of $114 \mathrm{MDa}$ (Toro \& Olivares, 1986), were used as size markers. Plasmid DNA was capillary-transferred to a nylon membrane according to Southern (1975) and immobilized by baking at $80^{\circ} \mathrm{C}$ for $2 \mathrm{~h}$.

Oligonucleotide primers and preparation of DNA probe. Oligonucleotide primers were designed to amplify a fragment of the nif $H$ gene that is conserved among members of the family Rhizobiaceae. These primers were: unifH1, 5'CTATGCCGCCAACAACATCG-3'; and unifH2, 5'-TTTGCATGGATCTTTTCAGCCA-3' (positions 635-654 and 888-910, respectively, of the $S$. meliloti nifH gene, accession no. J01781). These oligonucleotides amplify a 276 bp DNA fragment. Total DNA from S. meliloti GR4 was used as the template. PCRs were carried out in $25 \mu 1$ volumes containing $1 \mathrm{ng}$ total DNA, 25 pmol each primer, $0 \cdot 1 \mathrm{mM}$ dNTPs and 2 U Taq DNA polymerase. Amplifications were performed with a DNA thermo-robocycler (Stratagene). The program used in this work was as follows: 1 cycle at $95^{\circ} \mathrm{C}$ for $5 \mathrm{~min} ; 30$ cycles of $95^{\circ} \mathrm{C}$ for $1 \mathrm{~min}, 65^{\circ} \mathrm{C}$ for $1 \mathrm{~min}$ and $72{ }^{\circ} \mathrm{C}$ for $30 \mathrm{~s}$; and 1 cycle at $72^{\circ} \mathrm{C}$ for $5 \mathrm{~min}$. Amplified product was purified from $1 \%$ agarose gel and used as template for PCR amplification-labelling with digoxigenin11-dUTP (Boehringer).

Hybridization was carried out under high-stringency conditions according to the supplier's instructions. Washing was carried out twice ( 5 min each) in $2 \times \mathrm{SSC}, 0.1 \% \mathrm{SDS}$ at room temperature and twice (15 min each) in $0.1 \times \mathrm{SSC}$, 


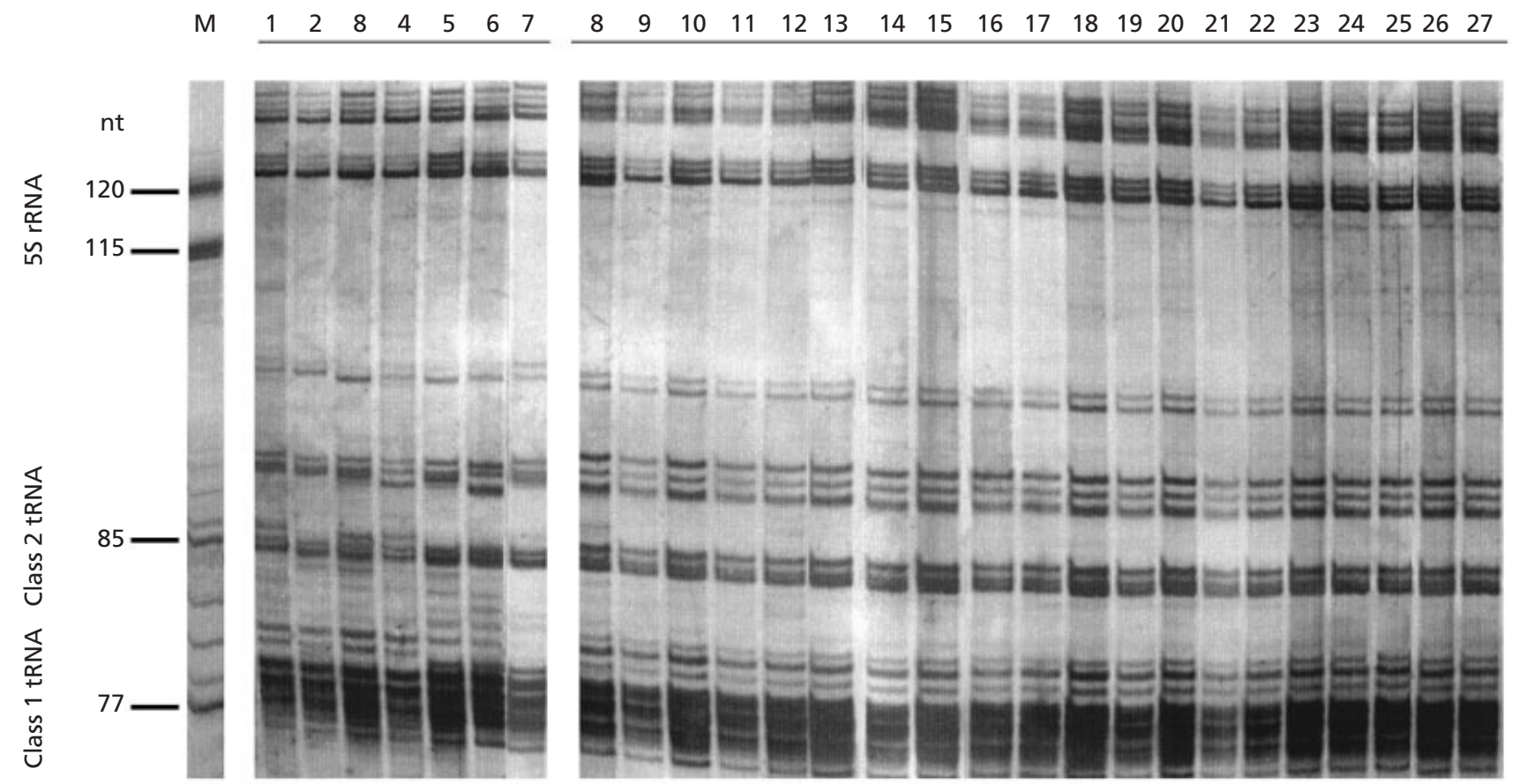

Fig. 1. LMW RNA profiles of the strains isolated in this study and type strains of genus Mesorhizobium. Lanes: $M$, molecular mass marker; 1 , M. tianshanense USDA $3592^{\top} ; 2, M$. mediterraneum USDA $3392^{\top} ; 3$, M. ciceri USDA 3383 ${ }^{\top} ; 4^{\text {, }}$ M. amorphae ACCC $19665^{\top} ; 5$, M. loti ATCC $33669^{\top} ; 6$, M. plurifarium LMG 11892 ${ }^{\top}$; 7, M. huakuii USDA 4779 ${ }^{\top}$; 8, M. chacoense LMG 19008' ${ }^{\top}$ 9, LMG 19009; 10, LMG 19010; 11, LMG 19011; 12, LMG 19012; 13, LMG 19013; 14, LMG 19014; 15, LMG 19015; 16, LMG 19016; 17, LMG 19017; 18, LMG 19018; 19, LMG 19019; 20, LMG 19020; 21, LMG 19021; 22, LMG 19022; 23, LMG 19023; 24, LMG 19024; 25, LMG 19025; 26, LMG 19026; and 27, LMG 19027.

$0 \cdot 1 \%$ SDS at $68{ }^{\circ} \mathrm{C}$. Detection of the hybridization signals was performed as specified by Boehringer Mannheim.

Morphological tests. Cell morphology was determined on Gram-stained cells and on living cells by phase-contrast microscopy.

Physiological and biochemical tests. The phenotypic characterization of strains isolated from Prosopis and type strains of the family Rhizobiaceae was based on $\mathrm{pH}$ changes for the different carbon sources (acid, basic or neutral), antibiotic resistance and extracellular enzyme production. The carbon sources were sucrose, galactose, lactose, L-arabinose, rhamnose, trehalose, maltose, adonitol, melibiose and raffinose. The basal medium comprised $\left(1^{-1}\right): 0 \cdot 2 \mathrm{~g} \mathrm{~K}_{2} \mathrm{HPO}_{4} ; 0 \cdot 2 \mathrm{~g}$ $\mathrm{MgSO}_{4} ; 1.0 \mathrm{~g} \mathrm{NH}_{4} \mathrm{NO}_{3} ; 1 \mathrm{ml}$ of a vitamin and trace element solution (Bergersen, 1961); and 0.05 g bromthymol blue. The $\mathrm{pH}$ was adjusted to $7 \cdot 0$ with $\mathrm{KH}_{2} \mathrm{PO}_{4}$. The discs with carbon sources (BBL; Becton Dickinson) were added under sterile conditions to $5 \mathrm{ml}$ medium. The results obtained were based on the $\mathrm{pH}$ changes for the different carbon sources (acid, basic or neutral) and were recorded after $5 \mathrm{~d}$ for fastgrowing species, $10 \mathrm{~d}$ for species of Mesorhizobium and $15 \mathrm{~d}$ for slow- and extra-slow-growing species. For testing antibiotic resistance, the following antibiotics were used: ampicillin, erythromycin, ciprofloxacin, penicillin, polymyxin, cloxacillin, oxytetracycline, gentamicin, cefuroxime and neomycin. The basal medium was YMB supplemented with $0.5 \%$ yeast extract. Each antibiotic disc was added under sterile conditions to $5 \mathrm{ml}$ basal medium.

For biochemical characterization, ten extracellular glucosidases were tested. The chromogenic substrates used were para-nitrophenyl substrates (PNP): PNP $\alpha$-D-arabino- pyranoside, PNP $\beta$-D-arabinopyranoside, PNP $\alpha$-D-fucopyranoside, PNP $\beta$-D-fucopyranoside, PNP $\alpha$-D-galactopyranoside, PNP $\beta$-D-galactopyranoside, PNP $\alpha$-D-xylopyranoside, PNP $\beta$-D-xylopyranoside, PNP $\alpha$-D-maltopyranoside and PNP $N$-acetylglucosaminide. Substrates were used at a concentration of $0.4 \%$ in $50 \mathrm{mM}$ phosphate buffer, $\mathrm{pH}$ 7. The enzymic reactions were carried out in multiwell plates by mixing $50 \mu \mathrm{l}$ substrate, prepared as specified above, and $50 \mu \mathrm{l}$ bacterial suspension in sterile water. The suspensions contained $6 \times 10^{9}$ c.f.u. $\mathrm{ml}^{-1}$. To make up the suspensions, plate cultures with the minimal medium of Bergersen (1961) were incubated at $28^{\circ} \mathrm{C}$ over $2 \mathrm{~d}$ for agrobacteria and phyllobacteria, $4 \mathrm{~d}$ for sinorhizobia, rhizobia and allorhizobia, $5 \mathrm{~d}$ for mesorhizobia and $8 \mathrm{~d}$ for bradyrhizobia and azorhizobia. The plates with the reaction mixture were incubated at $28{ }^{\circ} \mathrm{C}$ and were developed with a solution of $4 \%$ sodium carbonate, adding $100 \mu \mathrm{l}$ to each well. Abilities to grow at 37 and $40{ }^{\circ} \mathrm{C}$ and at $\mathrm{pH} 5$ and 8 were determined on YMA medium.

\section{RESULTS}

\section{Isolation and nodulation}

All of the isolates grew slowly in YMA medium and were effective for symbiotic nitrogen fixation in the three species of Prosopis used in this study. Nitrogen fixation was confirmed as effective based on the nodulation and growth of plants for several months in nitrogen-free medium. None of strains was able to nodulate Acacia sp. All of the strains induced indeterminate nodules in Prosopis. 


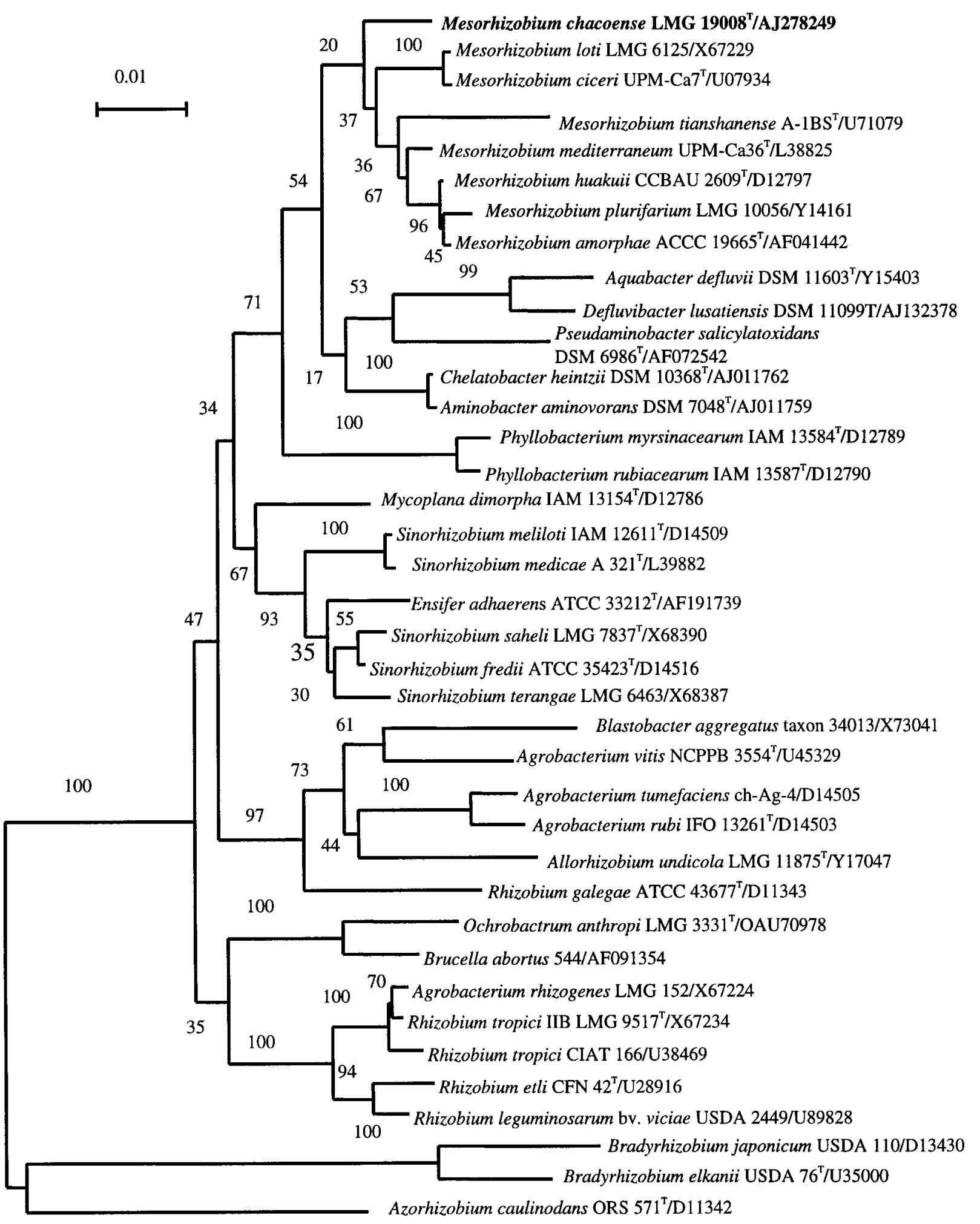

Fig. 2. Phylogenetic tree of rhizobia and some related bacteria in the $\alpha$-Proteobacteria. The tree was constructed by the neighbour-joining method from 16S rRNA sequences. Bootstrap probability values greater than $50 \%$ are indicated at the branch-points. Bar, 0.01 substitutions per site. Sequences were derived from the type strains wherever possible. 


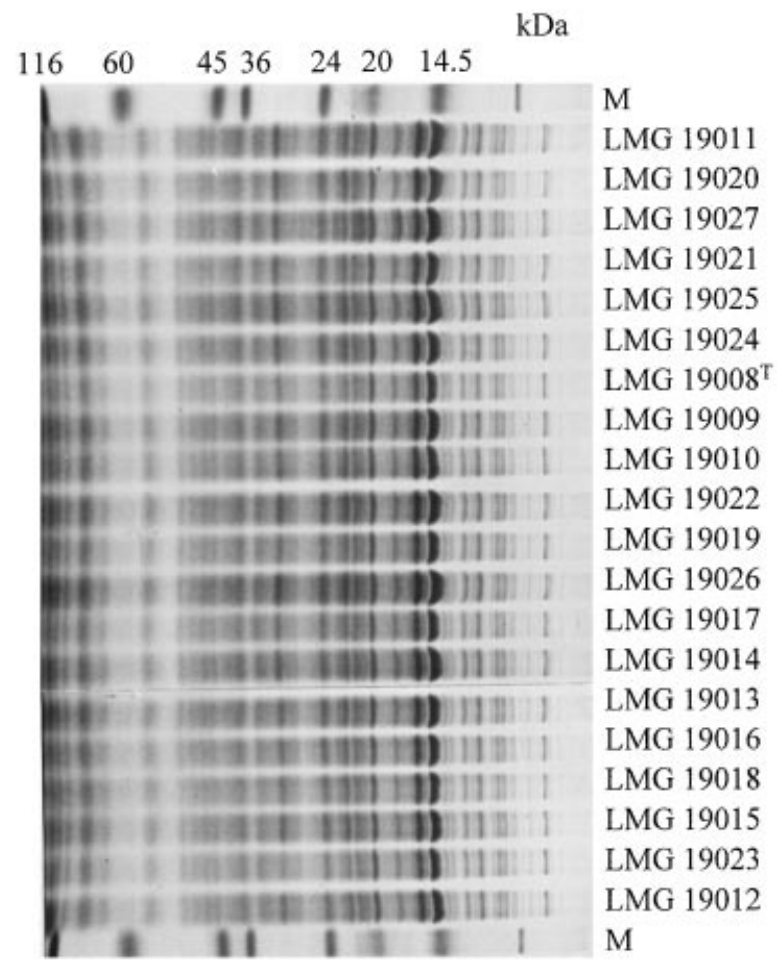

Fig. 3. SDS-PAGE protein profiles of Prosopis isolates. Lanes M, molecular mass markers.

\section{LMW RNA profiles}

The LMW RNA profiles of strains isolated from Prosopis in this study are shown in Fig. 1. All strains had the same LMW RNA profile (Fig. 1, lanes 8-27), indicating that they belong to the same genus and species.

In the LMW RNA profiles, three zones can be distinguished: 5S RNA, class 1 tRNA and class 2 tRNA. The 5S rRNA zone is characteristic of each bacterial genus and the tRNA zone is characteristic of each bacterial species. The 5S rRNA zone of the LMW RNA profile of all strains isolated from Prosopis in the Chaco Arido was similar to that of the genus Mesorhizobium. Therefore, all strains isolated in this study should be included in this genus. However, the tRNA profile of these strains differed from that of the currently accepted species of this genus (Fig. 1, lanes 1-7). This result indicates that the strains studied probably represent a novel species of the genus Mesorhizobium.

\section{S rDNA sequence analysis}

Strain LMG $19008^{\mathrm{T}}$ is proposed as the type strain of the group of rhizobia isolated from Prosopis in this study and the complete nucleotide sequence of its $16 \mathrm{~S}$ rDNA was obtained and compared with those of other members of the $\alpha$-Proteobacteria available in the databases. The results confirmed those obtained from the LMW RNA analysis. The phylogenetic tree obtained with this method indicated that strain LMG $19008^{\mathrm{T}}$ was related to Mesorhizobium, but formed a separate branch in this genus (Fig. 2). A search of the EMBL database revealed the new sequence to be most similar to the $16 \mathrm{~S}$ rRNA sequences of species of Mesorhizobium. The similarity of the 16S rRNA sequence of $M$. chacoense sp. nov. to those of the type strains from all Mesorhizobium species was $98 \%$ or higher. Similarity to sequences of species from other closely related genera such as Chelatobacter or Aminobacter was lower than $98 \%$. Based on these values, it is considered that the novel species proposed in the present work belongs to the genus Mesorhizobium.

\section{Analysis of proteins by SDS-PAGE}

Reproducibility was verified by preparing extracts in duplicate. Duplicate strains clustered above $93 \%$ (data not shown). Protein extracts of the newly isolated strains showed a striking similarity (Fig. 3) and clustered at $93 \%$ or higher (Fig. 4), indicating considerable homogeneity among the strains. Comparison of their SDS-PAGE profiles to those of other Mesorhizobium strains revealed that none of the protein profiles of these organisms was highly similar to those of the new group (Fig. 4).

\section{DNA-DNA hybridizations and DNA base composition}

The microplate method used in this study was generally in good agreement with the optical renaturation rate method (Goris et al., 1998). In view of the very high similarity of the protein profiles of the isolates, confirmed by total identity in LMW RNA profiles, only two representative strains were used for DNADNA hybridizations. As expected, they showed a high degree of DNA relatedness $(100 \%)$. With hybridization values of $2-17 \%$, none of the known species of Mesorhizobium showed a significant degree of DNA relatedness to the new group. The $\mathrm{G}+\mathrm{C}$ contents of genomic DNA of strains LMG $19008^{\mathrm{T}}$ and LMG 19022, as determined by HPLC, were 61.71 and 61.55 $\mathrm{mol} \%$.

\section{Plasmid profiles}

Figure 5 shows the results of the plasmid profile analysis of strain LMG $19008^{\mathrm{T}}$ (lane 1). All strains isolated from Prosopis in this study had plasmid profiles identical to that of the type strain (data not shown), with a unique plasmid of approximately $1000 \mathrm{MDa}$ (data not shown). None of these plasmids hybridized with the probe of the nifH gene used in this study.

\section{Physiological and biochemical characteristics}

The results of physiological and biochemical tests are shown in Table 2. Different carbon sources were tested in a minimal medium with ammonium nitrate as the 


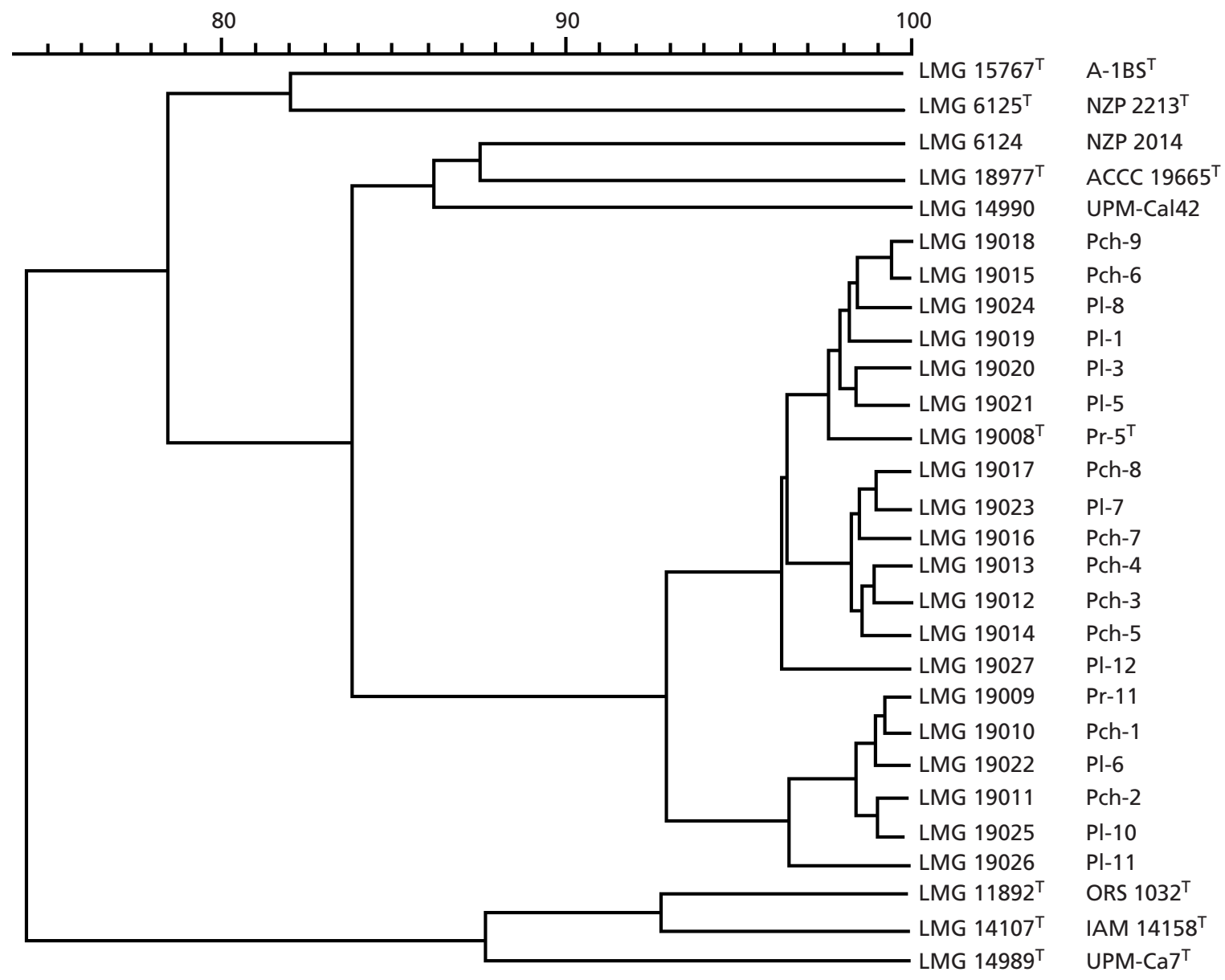

Fig. 4. Dendrogram showing the relationships between the electrophoretic protein patterns from Prosopis isolates and reference strains of Mesorhizobium species. The mean correlation coefficient $(r)$ was represented as a dendrogram constructed by the unweighted pair group method with arithmetic means. Scale bar, $r$ value converted to a percentage.

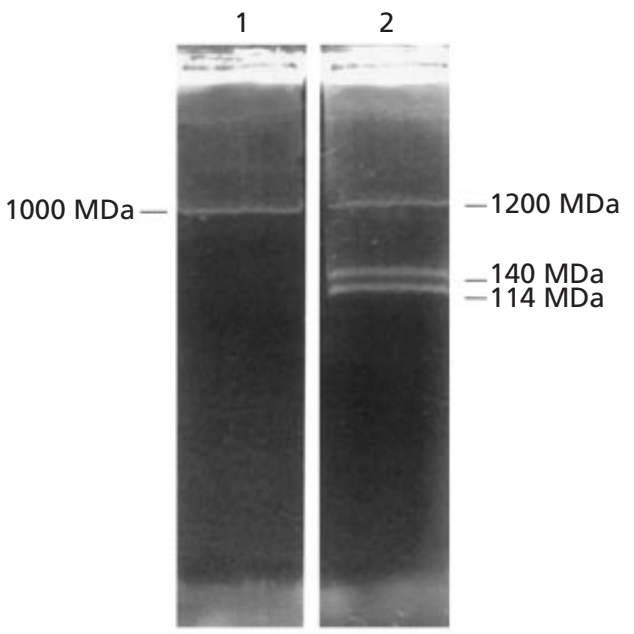

Fig. 5. Plasmid profiles of Prosopis strains isolated in this study. Lanes: 1, M. chacoense LMG $19008^{\top}$; 2, S. meliloti GR4. nitrogen source. Four types of response can be expected in this medium: $\mathrm{pH}$ changes to acid; $\mathrm{pH}$ changes to basic; no change of $\mathrm{pH}$, but growth detected; or no change of $\mathrm{pH}$ and no growth detected. The type strains of Agrobacterium tumefaciens, Azorhizobium caulinodans and Bradyrhizobium japonicum produced a basic $\mathrm{pH}$ in this medium, whereas most other strains produced an acid $\mathrm{pH}$ from the sugars used in this study. In general, the strains isolated from Prosopis in this study produced acid from these sugars, with the exception of raffinose.

Growth in the presence of ten antibiotics with different structural groups was also tested. Because some of the strains used in this study are slow growers, liquid medium (YMB) was used, as in the above experiment. The pattern of resistance to antibiotics allows the differentiation of the species of the family Rhizobiaceae. All strains isolated from Prosopis in this study showed the same pattern of resistance to the antibiotics.

Finally, several extracellular enzymic activities were detected using PNP substrates, which are easily detected from plate cultures. The results of extracellular 
Table 2. Physiological and biochemical characteristics of rhizobia used in this study

The type strain of each species was used (see Table 1). +, Positive result; -, negative result or no growth (in the case of the carbon source utilization); A, acid; B, basic; N, neutral. Species are indicated as: 1, A. undicola; 2, R. galegae; 3, R. leguminosarum; 4, S. meliloti; 5, M. ciceri; 6, M. mediterraneum; 7, M. loti; 8, M. huakuii; 9, M. tianshanense; 10, M. plurifarium; 11, M. amorphae; 12, M. chacoense; 13, B. japonicum; 14, A. caulinodans; 15, A. tumefaciens; 16, P. myrsinacearum. Abbreviations: PNP $\alpha$-Dara, PNP $\alpha$-D-arabinopyranoside; PNP $\beta$-Dara, PNP $\beta$-D-arabinopyranoside; PNP $\alpha$-Lfuco, PNP $\alpha$-L-fucopyranoside; PNP $\beta$-Dfuco, PNP $\beta$-D-fucopyranoside; PNP $\alpha$-Dgal, PNP $\alpha$-D-galactopyranoside; PNP $\beta$-Dgal, PNP $\beta$-D-galactopyranoside; PNP $\alpha$-Dxyl, PNP $\alpha$-D-xylopyranoside; PNP $\beta$-Dxyl, PNP $\beta$-D-xylopyranoside; PNP $\alpha$-Dmal, PNP $\alpha$-D-maltopyranoside; PNP $N$-acglc, PNP $N$-acetylglucosaminide. All species were resistant to cloxacillin.

\begin{tabular}{|c|c|c|c|c|c|c|c|c|c|c|c|c|c|c|c|c|}
\hline Character & 1 & 2 & 3 & 4 & 5 & 6 & 7 & 8 & 9 & 10 & 11 & 12 & 13 & 14 & 15 & 16 \\
\hline \multicolumn{17}{|c|}{ Carbon source utilization: } \\
\hline Sucrose & A & A & A & A & A & A & A & A & A & $\mathrm{B}$ & A & A & - & $\mathrm{B}$ & $\mathrm{B}$ & A \\
\hline Galactose & A & A & A & A & A & A & A & A & A & A & A & A & $\mathrm{B}$ & $\mathrm{B}$ & $\mathrm{B}$ & A \\
\hline Lactose & A & A & A & A & A & A & A & A & A & A & A & A & - & $\mathrm{B}$ & $\mathrm{B}$ & - \\
\hline L-Arabinose & A & A & A & A & A & A & A & A & $\mathrm{A}$ & A & A & A & $\mathrm{B}$ & B & $\mathrm{B}$ & A \\
\hline Rhamnose & A & A & $\mathrm{A}$ & A & A & $\mathrm{A}$ & A & A & A & A & A & A & $\mathrm{N}$ & $\mathrm{B}$ & $\mathrm{B}$ & A \\
\hline Trehalose & A & A & A & A & A & A & A & A & A & A & A & A & - & $\mathrm{B}$ & B & A \\
\hline Maltose & A & A & A & A & A & A & A & A & A & A & A & A & - & A & $\mathrm{B}$ & A \\
\hline Adonitol & - & A & A & $\mathrm{A}$ & A & A & A & A & $\mathrm{B}$ & A & A & A & $\mathrm{B}$ & $\mathrm{B}$ & $\mathrm{B}$ & A \\
\hline Melibiose & - & A & A & A & $\mathrm{N}$ & A & A & A & A & A & A & A & A & $\mathrm{B}$ & B & A \\
\hline Raffinose & - & A & A & $\mathrm{A}$ & $\mathrm{N}$ & $\mathrm{B}$ & A & A & - & $\mathrm{B}$ & A & $\mathrm{N}$ & - & $\mathrm{B}$ & $\mathrm{B}$ & A \\
\hline \multicolumn{17}{|c|}{ Antibiotic resistance: } \\
\hline Ampicillin & - & - & + & + & - & - & - & - & - & - & + & - & + & + & + & + \\
\hline Erythromycin & + & - & + & + & + & + & + & + & + & + & + & + & + & + & + & + \\
\hline Ciprofloxacin & - & - & - & + & - & - & - & - & - & + & - & + & + & + & - & - \\
\hline Penicillin & - & - & + & + & - & - & - & - & - & - & + & - & + & + & + & + \\
\hline Polymyxin & - & - & - & - & + & - & + & + & - & + & - & - & + & + & - & + \\
\hline Oxytetracycline & - & - & - & - & - & - & - & - & - & - & + & - & + & - & - & + \\
\hline Gentamicin & - & - & - & - & + & - & - & - & - & - & - & - & + & - & - & - \\
\hline Cefuroxime & - & - & + & + & - & - & - & - & - & - & - & - & + & + & + & - \\
\hline Neomycin & + & + & - & - & + & - & + & + & - & + & + & - & + & + & + & + \\
\hline \multicolumn{17}{|c|}{ Enzyme activity against: } \\
\hline PNP $\alpha$-Dara & + & + & + & + & - & - & - & - & - & - & + & - & - & - & + & - \\
\hline PNP $\beta$-Dara & - & - & + & + & + & - & + & - & - & - & + & - & - & - & + & - \\
\hline PNP $\alpha$-Lfuco & - & - & + & - & - & - & - & - & - & - & - & - & - & - & - & - \\
\hline PNP $\beta$-Dfuco & + & + & + & + & - & - & - & - & - & - & + & - & + & - & + & - \\
\hline PNP $\alpha$-Dgal & + & - & + & + & + & - & - & + & - & + & + & - & - & - & + & - \\
\hline PNP $\beta$-Dgal & + & + & + & + & - & - & - & - & - & - & + & - & - & - & + & - \\
\hline PNP $\alpha$-Dxyl & - & - & + & - & - & + & - & - & + & - & + & - & - & - & + & - \\
\hline PNP $\beta$-Dxyl & - & + & + & + & + & + & + & - & + & - & + & + & - & - & + & - \\
\hline $\operatorname{PNP} \alpha$-Dmal & - & - & + & + & - & + & - & - & - & - & + & + & - & - & + & - \\
\hline PNP $N$-acglc & + & + & + & + & + & + & + & + & + & + & + & + & - & - & + & + \\
\hline
\end{tabular}

enzyme production show that the species of the family Rhizobiaceae have a different pattern of glycosidase production. All strains isolated from Prosopis in this study showed the same pattern of extracellular enzymes.

\section{DISCUSSION}

The application of new molecular techniques to the classification and description of new species and genera has, in the last few decades, led to a large increase in the size of the family Rhizobiaceae, for example through the description of several new genera (Mesorhizobium, Allorhizobium). One of them, the genus
Mesorhizobium (Jarvis et al., 1997), includes a group of species related to Mesorhizobium loti and obtained from a diverse range of host legumes including Lupinus, Ornithopus, Lotus, Anthillis, Caragena, Astragalus, Ononis, Genista, Mimosa, Cicer and Leucaena. At the time of description of the genus, it included the species Mesorhizobium ciceri (Nour et al., 1994), Mesorhizobium huakuii (Chen et al., 1991), M. loti (Jarvis et al., 1982), Mesorhizobium mediterraneum (Nour et al., 1995) and Mesorhizobium tianshanense (Chen et al., 1995). Later, two new species were described: M. plurifarium, for a group of isolates from Acacia, Leucaena, Prosopis and Chamaecrista (de Lajudie et al., 1998a), and Mesorhizobium amorphae, 
corresponding to a group of isolates from Amorpha fruticosa (Wang et al., 1999).

Some legumes, such as Prosopis, are indigenous to the American continent and have been cultivated in other geographical locations since the fifteenth century. The adaptation of these legumes to new habitats can include the nodulation of their roots by different genera and species of rhizobia in each soil. Thus, it is of great interest to study the populations that nodulate Prosopis in large ecosystems in South America, because the symbionts of Prosopis in America have not been extensively studied.

Stable LMW RNAs are molecules whose interest for taxonomic purposes lies in their presence in all cells from the beginning of evolution, in the fact that they always play the same role (protein synthesis, an indispensable function for cell growth) and in their ubiquitous distribution in living beings. SCE allows an optimal separation of these molecules (Cruz-Sánchez et al., 1997). This technique has already been applied to genera and species of the family Rhizobiaceae, obtaining different profiles for each bacterial species assayed (Velázquez et al., 1998a, b). Therefore, LMW RNA profiles allow rapid analysis of populations of bacteria and permit rapid identification of species and genera from the family Rhizobiaceae and the detection of new ones.

Analysis of the LMW RNA profiles of the strains isolated in this study showed that: (i) all strains isolated from Prosopis in this study displayed the same LMW RNA profile and, therefore, should be included in the same genus and species; (ii) the 5S rRNA zone of their profile indicated that these strains should be included in the genus Mesorhizobium; and (iii) the tRNA profile of strains studied indicated that these strains should be included in a novel species of this genus.

Analysis of the 16S rRNA sequence of strain LMG $19008^{\mathrm{T}}$ confirmed the results obtained from the LMW RNA profiles. As can be seen in Fig. 2, this strain grouped with the other species of Mesorhizobium, although this grouping was not strongly supported in the bootstrap analysis. Strain LMG $19008^{\mathrm{T}}$ formed a new and separate line (Fig. 2) in the Mesorhizobium group, with sequence similarities of $98 \cdot 0-98 \cdot 4 \%$ to the other Mesorhizobium species. The degree of similarity to $16 \mathrm{~S}$ rRNA sequences of other closely related genera such as Chelatobacter or Aminobacter was lower than $98 \%$. Results obtained by SDS-PAGE of whole-cell protein extracts also confirmed those obtained by LMW RNA analysis. The results showed high similarity among the patterns of strains isolated from Prosopis in this study (Fig. 3) and low similarity between the patterns of these strains and those of other species of Mesorhizobium (Fig. 4). Results obtained for DNA-DNA hybridization showed that the two representative strains, LMG $19008^{\mathrm{T}}$ and LMG 19022, were very closely related and their homology to the others species of Mesorhizobium was low. Thus, it is concluded that the strains isolated in this study constitute a novel species of the genus Mesorhizobium.

All strains of Prosopis isolated in this study had the same patterns of resistance to antibiotics and of exoglucosidase production, but variations could be observed in the assimilation of carbon sources (Table 2). Comparison of phenotypic results for the Prosopis strains, strains representing other Mesorhizobium species and some related species showed that the novel isolates could be differentiated from all other taxa studied.

Results of all the above techniques, 16S rDNA sequencing, LMW RNA profiling, SDS-PAGE protein analysis, DNA-DNA hybridization and phenotypic analysis, thus corroborate and complement each other very well and lead to a similar conclusion. A novel species, Mesorhizobium chacoense sp. nov., is therefore proposed for the Prosopis isolates from the Chaco Arido (Argentina).

\section{Description of Mesorhizobium chacoense sp. nov.}

Mesorhizobium chacoense (cha.co.en'se. N.L. neut. adj. chacoense from El Chaco, Argentina, where the type strain was isolated).

Gram-negative, aerobic, motile, non-spore-forming rods. Colonies on YMA are circular, convex, white, opaque and usually $1-3 \mathrm{~mm}$ in diameter within $7 \mathrm{~d}$ at $28^{\circ} \mathrm{C}$. Maximum temperature for growth is $37^{\circ} \mathrm{C}$. The generation times are 10-24 h in YM broth. Strains of this species produce acid from sucrose, galactose, lactose, L-arabinose, rhamnose, trehalose, maltose, adonitol and melibiose in media with ammonium nitrate as nitrogen source. These strains are resistant to erythromycin, ciprofloxacin and cloxacillin. All strains produce $\beta$-xylosidases, $\alpha$-maltosidases and $N$-acetylglucosaminidases. This species shows the 5S rRNA zone in LMW RNA profiles typical of the genus Mesorhizobium. All strains have the same tRNA profile. The plasmid present in the strains did not carry the nifH gene. The type strain, LMG $19008^{\mathrm{T}}$ (= CECT $5336^{\mathrm{T}}$ ), has the characteristics described for this species. The $\mathrm{G}+\mathrm{C}$ content of genomic DNA of strains LMG $19008^{\mathrm{T}}$ and LMG 19022, as determined by HPLC, is $62 \mathrm{~mol} \%$.

\section{ACKNOWLEDGEMENTS}

This work was initiated by a Proyecto de Investigación Conjunta del Programa de Cooperación Científica con Iberoamérica del Ministerio de Educación y Cultura to A.A. and E.C. and supported by Junta de Castilla y León to E.M. and E.V. M.G. and A. W. are grateful to the Fund for Scientific Research, Flanders, for research and personnel grants and a position as a Postdoctoral Research Fellow, respectively. 


\section{REFERENCES}

Altschul, S. F., Gish, W., Miller, W., Myers, E. W. \& Lipman, D. J. (1990). Basic local alignment search tool. J Mol Biol 215, 403-410.

Bergersen, F. J. (1961). The growth of Rhizobium in synthetic media. Aust J Biol 14, 349-360.

Bidle, K. D. \& Fletcher, M. (1995). Comparison of free-living and particle-associated bacterial communities in the Chesapeake Bay by stable low-molecular-weight RNA analysis. Appl Environ Microbiol 61, 944-952.

Chen, W. X., Li, G. S., Qi, Y. L., Wang, E. T., Yuan, H. L. \& Li, J. L. (1991). Rhizobium huakuii sp. nov., isolated from the root nodules of Astragalus sinicus. Int J Syst Bacteriol 41, 275-280.

Chen, W., Wang, E., Wang, S., Li, Y., Chen, X. \& Li, Y. (1995). Characteristics of Rhizobium tianshanense sp. nov., a moderately and slowly growing root nodule bacterium isolated from an arid saline environment in Xinjiang, People's Republic of China. Int J Syst Bacteriol 45, 153-159.

Cruz-Sánchez, J. M., Velázquez, E., Mateos, P. F. \& MartínezMolina, E. (1997). Enhancement of resolution of low molecular weight RNA profiles by staircase electrophoresis. Electrophoresis 18, 1909-1911.

Dreyfus, B., Garcia, J. L. \& Gillis, M. (1988). Characterization of Azorhizobium caulinodans gen. nov., sp. nov., a stem-nodulating nitrogen-fixing bacterium isolated from Sesbania rostrata. Int $J$ Syst Bacteriol 38, 89-98.

Ezaki, T., Hashimoto, Y. \& Yabuuchi, E. (1989). Fluorometric deoxyribonucleic acid-deoxyribonucleic acid hybridization in microdilution wells as an alternative to membrane filter hybridization in which radioisotopes are used to determine genetic relatedness among bacterial strains. Int J Syst Bacteriol 39, 224-229.

Faulkner, D. V. \& Jurka, J. (1988). Multiple aligned sequence editor (MASE). Trends Biochem Sci 13, 321-322.

Goris, J., Suzuki, K., De Vos, P., Nakase, T. \& Kersters, K. (1998). Evaluation of a microplate DNA-DNA hybridization method compared with the initial renaturation method. Can J Microbiol 44, 1148-1153.

Haas, H., Budowle, B. \& Weiler, G. (1994). Horizontal polyacrylamide gel electrophoresis for the separation of DNA fragments. Electrophoresis 15, 153-158.

Haukka, K., Lindström, K. \& Young, J. P. W. (1996). Diversity of partial 16S rRNA sequences among and within strains of African rhizobia isolated from Acacia and Prosopis. Syst Appl Microbiol 19, 352-359.

Höfle, M. G. (1988). Identification of bacteria by low molecular weight RNA profiles: a new chemotaxonomic approach. $J$ Microbiol Methods 8, 235-248.

Jarvis, B. D. W., Pankhurst, C. E. \& Patel, J. J. (1982). Rhizobium loti, a new species of legume root nodule bacteria. Int J Syst Bacteriol 32, 378-380.

Jarvis, B. D. W., van Berkum, P., Chen, W. X., Nour, S. M., Fernandez, M. P., Cleyet-Marel, J. C. \& Gillis, M. (1997). Transfer of Rhizobium loti, Rhizobium huakuii, Rhizobium ciceri, Rhizobium mediterraneum, and Rhizobium tianshanense to Mesorhizobium gen. nov. Int J Syst Bacteriol 47, 895-898.

Jordan, D. C. (1982). Transfer of Rhizobium japonicum Buchanan 1980 to Bradyrhizobium gen. nov., a genus of slow-growing, root nodule bacteria from leguminous plants. Int $J$ Syst Bacteriol 32, 136-139.
Kersters, K. \& De Ley, J. (1984). Genus III. Agrobacterium Conn 1942, 359 ${ }^{\mathrm{AL}}$. In Bergey's Manual of Systematic Bacteriology, vol. 1, pp. 244-254. Edited by N. R. Krieg \& J. G. Holt. Baltimore: Williams \& Wilkins.

Kimura, M. (1980). A simple method for estimating evolutionary rates of base substitutions through comparative studies of nucleotide sequences. J Mol Evol 16, 111-120.

Knösel, D. H. (1984). Genus IV. Phyllobacterium (ex Knösel 1962) nom. rev. (Phyllobacterium Knösel 1962, 96). In Bergey's Manual of Systematic Bacteriology, vol. 1, pp. 254-256. Edited by N. R. Krieg \& J. G. Holt. Baltimore: Williams \& Wilkins.

de Lajudie, P., Willems, A., Pot, B. \& 7 other authors (1994). Polyphasic taxonomy of Rhizobia: emendation of the genus Sinorhizobium and description of Sinorhizobium meliloti comb. nov., Sinorhizobium saheli sp. nov., and Sinorhizobium teranga sp. nov. Int J Syst Bacteriol 44, 715-733.

de Lajudie, P., Willems, A., Nick, G. \& 9 other authors (1998a). Characterization of tropical tree rhizobia and description of Mesorhizobium plurifarium sp. nov. Int J Syst Bacteriol 48, 369-382.

de Lajudie, P., Laurent-Fulele, E., Willems, A., Torck, U., Coopman, R., Collins, M. D., Kersters, K., Dreyfus, B. \& Gillis, M. (1998b). Allorhizobium undicola gen. nov., sp. nov., nitrogen-fixing bacteria that efficiently nodulate Neptunia natans in Senegal. Int $J$ Syst Bacteriol 48, 1277-1290.

Lindström, K. (1989). Rhizobium galegae, a new species of legume root nodule bacteria. Int J Syst Bacteriol 39, 365-367.

Mclnroy, S. G., Campbell, C. D., Haukka, K. E., Odee, D. W., Sprent, J. I., Wang, W. J., Young, J. P. W. \& Sutherland, J. M. (1999). Characterisation of rhizobia from African acacias and other tropical woody legumes using Biolog and partial $16 \mathrm{~S}$ rRNA sequencing. FEMS Microbiol Lett 170, 111-117.

Mesbah, M., Premachandran, U. \& Whitman, W. B. (1989). Precise measurement of the $\mathrm{G}+\mathrm{C}$ content of deoxyribonucleic acid by high-performance liquid chromatography. Int $J$ Syst Bacteriol 39, 159-167.

Normand, P., Orso, S., Cournoyer, B., Jeannin, P., Chapelon, C., Dawson, J., Evtushenko, L. \& Misra, A. K. (1996). Molecular phylogeny of the genus Frankia and related genera and emendation of family Frankiaceae. Int J Syst Bacteriol 46, 1-9.

Nour, S. M., Fernandez, M. P., Normand, P. \& Cleyet-Marel, J.-C. (1994). Rhizobium ciceri sp. nov., consisting of strains that nodulate chickpeas (Cicer arietinum L.). Int J Syst Bacteriol 44, 511-522.

Nour, S. M., Cleyet-Marel, J.-C., Normand, P. \& Fernandez, M. P. (1995). Genomic heterogeneity of strains nodulating chickpeas (Cicer arietinum L.) and description of Rhizobium mediterraneum sp. nov. Int J Syst Bacteriol 45, 640-648.

Pitcher, D., Saunders, N. \& Owen, R. (1989). Rapid extraction of bacterial genomic DNA with guanidinium thiocyanate. Lett Appl Microbiol 8, 151-156.

Plazinski, J., Chen, Y. H. \& Rolfe, B. G. (1985). General method for the identification of plasmid species in fast-growing soil microorganisms. Appl Environ Microbiol 48, 1001-1003.

Pot, B., Vandamme, P. \& Kersters, K. (1994). Analysis of electrophoretic whole-organism protein fingerprints. In Modern Microbial Methods (Chemical Methods in Prokaryotic Systematics Series), pp. 493-521. Edited by M. Goodfellow \& A. G. O'Donnell. Chichester: Wiley.

Rigaud, J. \& Puppo, A. (1975). Indole-3-acetic catabolism by soybean bacteroids. J Gen Microbiol 88, 223-228. 
Ritchie, N. J. \& Myrold, D. D. (1999). Phylogenetic placement of uncultured Ceanothus microsymbionts using 16S rRNA gene sequences. Can J Bot 77, 1208-1213.

Saitou, N. \& Nei, M. (1987). The neighbor-joining method: a new method for reconstructing phylogenetic trees. Mol Biol Evol 4, 406-425.

Skerman, V. B. D., McGowan, V. \& Sneath, P. H. A. (1980). Approved lists of bacterial names. Int J Syst Bacteriol 30, 225-420.

Southern, E. M. (1975). Detection of specific sequences among DNA fragments separated by gel electrophoresis. J Mol Biol 98, 503-517.

Sprinzl, M., Moll, J., Meissner, F. \& Hartmann, T. (1985). Compilation of tRNA sequences. Nucleic Acids Res 13 (Suppl.), $1-49$.

Thompson, J. D., Gibson, T. J., Plewniak, F., Jeanmougin, F. \& Higgins, D. G. (1997). The CLUSTAL-X windows interface: flexible strategies for multiple sequence alignment aided by quality analysis tools. Nucleic Acids Res 25, 4876-4882.
Toro, N. \& Olivares, J. (1986). Characterization of a large plasmid of Rhizobium meliloti involved in enhancing nodulation. Mol Gen Genet 202, 331-335.

Velázquez, E., Cruz-Sánchez, J. M., Mateos, P. F. \& MartínezMolina, E. (1998a). Analysis of stable low-molecular-weight RNA profiles of members of the family Rhizobiaceae. Appl Environ Microbiol 64, 1555-1559.

Velázquez, E., Cervantes, E., Igual, J. M. \& 9 other authors (1998b). Analysis of LMW RNA profiles of Frankia strains by staircase electrophoresis. Syst Appl Microbiol 21, 539-545.

Vincent, J. M. (1970). The cultivation, isolation and maintenance of rhizobia. In A Manual for the Practical Study of RootNodules, pp. 1-13. Edited by J. M. Vincent. Oxford: Blackwell Scientific.

Wang, E. T., van Berkum, P., Sui, X. H., Beyene, D., Chen, W. X. \& Martínez-Romero, E. (1999). Diversity of rhizobia associated with Amorpha fruticosa isolated from Chinese soils and description of Mesorhizobium amorphae sp. nov. Int J Syst Bacteriol 49, 51-65. 